\title{
THE DEVELOPMENT OF LEARNING MULTIMEDIA TO IMPROVE ENGLISH COMMUNICATION SKILLS
}

\author{
Leny Meidiantary \\ Universitas Tanjungpura, Pontianak, Indonesia \\ E-mail:lenymeidiantary@yahoo.com
}

\begin{abstract}
This study aims to find out the development of learning multimedia through multimedia development design with material welcoming guests and registering guests at the Hotel, as well as to see how to improve English communication skills using learning multimedia with research subjects in XI grade of Hospitality Accommodation in Pontianak 5 State Vocational High School study the material. The research method used in this research is the development research method by combining the Borg \& Gall development model with the Assure learning design model. Data obtained through interviews, observations and tests applied to the subject of the study. The flow of this research is carried out through three main stages, namely: (1) Product development plan phase which includes needs analysis, learning planning, (2) product development phase, which includes analysis of media forms, outlining media program contents, making flowcharts, collecting materials, making programs and (3) testing and revision stages which included small group trial, initial product revisions, second trial (medium scale), product revisions from the results of the second trial, field trial (large scale). The results of the study showed an increase in the presentation using learning multimedia starting from 2.80 from the value of the small group trial, 3.01 for the second trial value and 3.36 for the trial implementation value. In improving English communication skills, the learning completeness increased from an average value of 69.08 to pretest to 83.50 for the posttest average. This means that the use of learning multimedia can contribute to improving the skills of students communicating English.
\end{abstract}

Keywords: Development; Learning Multimedia; Communication Skills

\section{INTRODUCTION}

The learning process is a communication process and takes place in a system to obtain knowledge or knowledge. As support for this learning, the media occupies a fairly important position as a component of the learning system. Without media, communication will not occur, and the communication process will not be able to take place optimally. The development of learning multimedia is needed so that learning becomes more effective, efficient and enjoyable to improve English communication skills.

According to Agus M. Hardjana (in Ngainun, 2017: 18) communication can be defined as "the process of delivering meaning in the form of ideas or information from someone to others through certain media" In people's communication not responding to words, but the meaning of words. Because of interaction, communication is a dynamic activity. As long as communication takes place, both at the sender and at the recipient, it keeps on giving and receiving the influence and impact of the communication.
Active and polite communication can give a sense of satisfaction or impression to guests or customers in the service sector. The communication skills are expected to be possessed by Vocational Middle School students in the field of tourism expertise. Especially in the Hospitality Accommodation expertise program. These skills are highly related between the objectives of the Hospitality Accommodation Expertise Program based on the Education Unit Level Curriculum (KTSP 2006), the vocational level is:

Carry out work in scope, Front Office as Receptionist, Reservation Clerk, Telephone Operators, and Porters. Carry out Housekeeping work as a Public Areas Attendant and Laundry Attendant.

A student is said to be ready to carry out fieldwork practices (PKL) or in the business world / industry if they have cognitive, affective and psychomotor abilities. The readiness of students in carrying out industrial work practices in hotels, one of which arises if satisfying skills competencies can be achieved by students after attending learning Providing Accommodation Services Reception and can communicate in English well. Communicating in 
English is very necessary because guests who come to the hotel are not only Indonesians but also foreigners from various countries who come to Indonesia to visit and stay for a while.

English is still an obstacle to communication and boring for students. That is because, there are still students who have difficulty in saying words, sentences and understanding the meaning and material discussed. In addition, the lack of vocabulary possessed by students also becomes a barrier in assembling into a sentence. So that students are not able to arrange sentences to convey an idea or idea.

According to Thornbury (2016), "The main problems of learners, speakers face two areas: knowledge factors and skills factors because the speaker lacks confidence." Knowledge factor meaning that students do not yet know the strategy in communicating and the skill factor means that students have not been skilled at communicating so that they do not feel confident.

According to Hermayawati (Journal of Socio-Humanities Vol.1 September 2010), "Mastery of English will open insight into the development of science and technology." Improving the quality of English communication can be achieved if you know the background of learning difficulties. Information about learning difficulties can be used as a basis for determining goals, methods, strategies and learning materials that are relevant to the needs of students.

The use of media in the learning process aims to create learning conditions that enable students to learn actively, pleasantly so that students can achieve maximum learning outcomes and communicate fluently. The selection and use of media must be guided by the learning objectives to be achieved by paying attention to the characteristics of students and the student learning environment.

One of the learning media that can be used as an alternative to provide variations in the learning process and improve the ability to master English vocabulary is learning multimedia. Learning multimedia is a teaching program that is accessed through a computer so that users can interact with it and get to know English through features that use English.

Skills are abilities that a person has and acquired through training and experience to do a task (John M Ivan Cevich, et al., 2006: 87). According to Ngainun Naim (2017: 17-180), the word communication comes from the Latin word Cum, which is a preposition meaning with and together with and unus, a number word that means one. Of the two words formed the communion nouns which in English became communion and meant togetherness. Unity, fellowship, association, association, relationships. For communication, effort and work are needed. From that word made verb communicate which means dividing something with someone, giving some to someone, exchanging, talking about something with someone, telling something to someone, chatting, exchanging thoughts, relating, making friends. The verb communicate finally used as an object of communication verb, or English communication, and in Indonesian is absorbed into communication. Literally, communication means notification, conversation, conversation, exchange of thoughts or relationships.

Indonesian communication experts provide limitations on communication, including Onong Uchayan (1986) in Abdulhak et al. (2015: 25), saying that communication is a process of conveying messages and feelings or feelings to others by using symbols or symbols as media. This opinion is based on the belief of Carl I. Hovland that communication is a process in which a communicator communicates a message of stimulus to change the behavior of others or communicants.

According to Cholin Cherry, (Tedjasustina, 1994: 12) communication is a process where the goal is to achieve a better mutual understanding of issues that are important for all parties concerned. The types of communication are of two kinds, namely non-verbal and verbal communication. Nonverbal communication according to Purba et al. (2005: 30 ), is communication without using words. The simple limitation is the first step to distinguish what is called vocal communication, namely the act of communication that uses words. Whereas, verbal communication is communication using words (verb), both oral and written (Purba et al., 2005: 75).

According to Cangara (1998: 23), communication skills are a person's ability to convey messages to the audience (recipient of the message). Furthermore, according to Nevizond Chatab (2007: 29), communication skills are the ability to make connections through human communication channels or media, so that the message or information can be understood well. Communication skill is not birth abilities and does not appear suddenly; it needs to be learned and trained (Supratik, 2003: 12).

The word media comes from Latin and is the plural form of the medium which literally means an intermediary or introduction, according to Arief S. Sadiman et al. (2014: 6). According to Miarso that media is everything that can be used to channel messages, which can stimulate the thoughts, feelings, attention, and willingness of students to learn, (in Wiarto 2016: 2). Gerlach \& Ely (in Wiarto 2016: 2), says that media, when understood broadly, is human, material, or event that builds conditions that make students able to obtain knowledge, skills, or attitudes. Heinrich et al., Quoted by Azhar Arsyad (2005) in Rusman et al. (2012: 169), suggested the learning media as follows, "The limit of the medium is the intermediary that delivers information between the source and the recipient."

The Educational Technology and Communication Association (Association of Education and Communication Technology / EACT) in America, limits media as a form and channel that people use to channel messages / information. Gagne (1970) states that media is part of the type of component in the student environment that can stimulate it to learn.

Based on some of the opinions above, it can be concluded that the media are all things or components that can be used to channel messages from the sender to the recipient so that they can stimulate the thoughts, feelings, concerns, and interests of students in the learning process. Learning media 
is a means of delivering learning messages related to the direct learning model that is by the way the teacher acts as the conveyor of information, and in this case, the teacher should use a variety of appropriate media.

\section{Methodology}

Research and development methods (Research and Development) is one type of research method. According to Sugiyono $(2016 ; 2)$, "research methods are scientific ways to obtain data with specific purposes and uses." This method can be used to produce a particular product and test the effectiveness of the product. Furthermore, Sukmadinata (2006: 164) states that research and development is a process to develop a new product or perfect existing products that can be accounted for. This means that in the process of working on a product there are steps that are systematically carried out and each step must be in accordance with the rules of research so that the results can be accounted for. Based on the expert definition above, the orientation of development research is the creation of a product. Various kinds of products that can be developed such as media, learning strategies or methods, and teaching materials.

This development research produced learning multimedia in the competence of Providing Reception Accommodation Services to improve English communication skills in XI grade students of Pontianak 5 State Vocational High School. It can be concluded that research and development is a process for developing products. The development of teaching materials is expected so that students can easily and pleasantly and achieve learning and learning goals by building skills concepts and learners can learn independently according to the ability of the students themselves.

For this type of data in this study are qualitative data, According to Sugiono (2016; 7), "Qualitative data are data in the form of words, sentences, gestures, facial expressions, charts, images, and photos." In this qualitative study, data in the form of comments and product improvement advice from material experts, media experts, interviews and observations. Data collection instruments through (a) Observation Sheet: This observation sheet is used to collect data about learning acquisition and learning implementation. The observer is tasked with observing the activities of students when learning Provides Accommodation Services Reception uses multimedia Lectora Inspire. The results of later observations to find out the value of the effectiveness of learning using multimedia Lectora inspire already fit the criteria that have been determined or not. (b) Interview Guidelines: This interview guide is used to retrieve data on the acquisition of competency understanding. Providing Accommodation Services Reception materials Welcoming and Registering Guests and about responses of students and teachers before and after using multimedia Lectora inspire, (c) Questionnaire (questionnaire): In this study researchers used an instrument in the form of a questionnaire. There are two types of questionnaires used in this study; the first is the student response questionnaire to the media that has been used in the learning process. The aim is to determine the effectiveness of the use of Lectora inspires learning media in the classroom. The second is the Questionnaire for validation of media development instruments given to experts to measure the level of validity of the instrument. (D) Documentation: The documentation used by researchers is cameras and mobile phones. The camera is used when researchers make observations to record events which, according to important researchers at an event, whether the shooting is in the form of photos or videos, while Handphone is used by researchers to record or record sound when collecting data, either during interviews or other needs.

\section{RESULTS AND DISCUSSION}

\section{A. Results}

The Lectora Inspire multimedia development design is a preliminary study carried out in identifying to design the Lectora Inspire multimedia design that will be used in learning activities. The researcher will gather much information needed for Lectora Inspire's multimedia development and development. For this reason, in planning the learning media, these constraints need to be considered in order to get a better solution. After seeing the basics above, the priority scale is set in the form of actions, namely: a. Designing a learning media in accordance with the learning design of Reception Accommodation Service Providing in XI Hospitality Accommodation in Pontianak 5 State Vocational High School.

b. The media created must cover 3 domains of learning outcomes.

c. Media must accommodate all learning styles of students in the classroom.

d. Media must attract learners' interest.

e. Media must be controlled in use by students.

f. Media must be easy to operate, meaning weak students in the computer field can also use it.

g. Media designed must be able to be used for independent learning and classical learning.

h. Media has a real impact on schools.

The delivery model gives students the freedom to choose the subject and explanation of the material can also be repeated to provide reinforcement of understanding with the needs of users. The learner's multimedia development process is through several stages based on researchers' research and advice from material experts, design experts and media experts who have been adapted to their respective expertise. Response to the prototype developed.

The product evaluation phase includes validation (expert judgment), small group trial and field trial or large groups. The trial was conducted to obtain complete data for analysis and was used as material for revision of the product produced in the form of learning media development Providing Accommodation Services Reception. The aspects that are the material for revising include the service component contents, presentation, language, and appearance.

\section{a. Material Expert Response}

Validation of expert learning material is intended to obtain input on the suitability of the objectives to be 
achieved, language, elements of message design and material systematics. The following is presented a graph of the results of material experts' assessment of the Lectora Inspire learning multimedia.

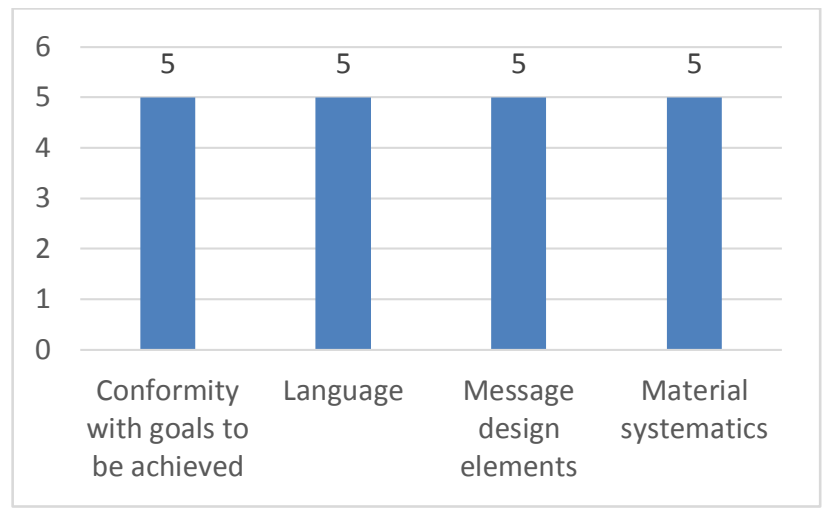

Fig. 1 The Results of Material Experts Assessment

In addition to providing assessments for improvements in revising multimedia Inspire, material experts also provide suggestions and comments so that multimedia can be maximally used by students.

\section{b. Response to Learning Design Experts}

Validation of learning design experts is intended to obtain input on learner goals, objectives with $\mathrm{SK} / \mathrm{KD}$, scope and depth of learning objectives, learning strategies, interactivity, learning motivation, contextuality and actuality, completeness and quality of learning aid materials. The following is a graph of the Learning Design expert's assessment of the Lectora Inspire learning multimedia.

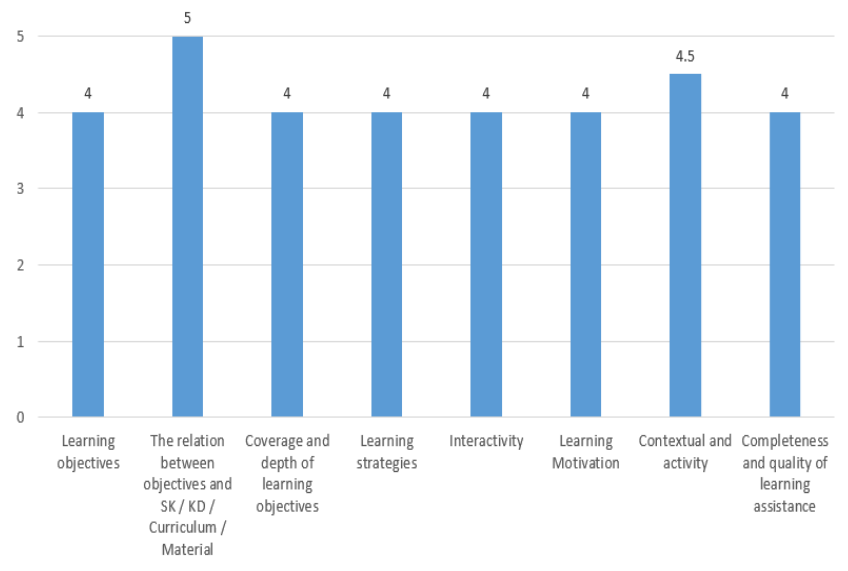

Fig. 2 Learning Design Experts Assessment Results

c. The response of Media Experts

Validation of media experts is intended to obtain input about Cover, images and aminations, colors, text, music or sound, grammar, layout, interactivity, and evaluation. Media Expert Responses The following is a graph of the assessment media expert's assessment of the Lectora Inspire learning multimedia.

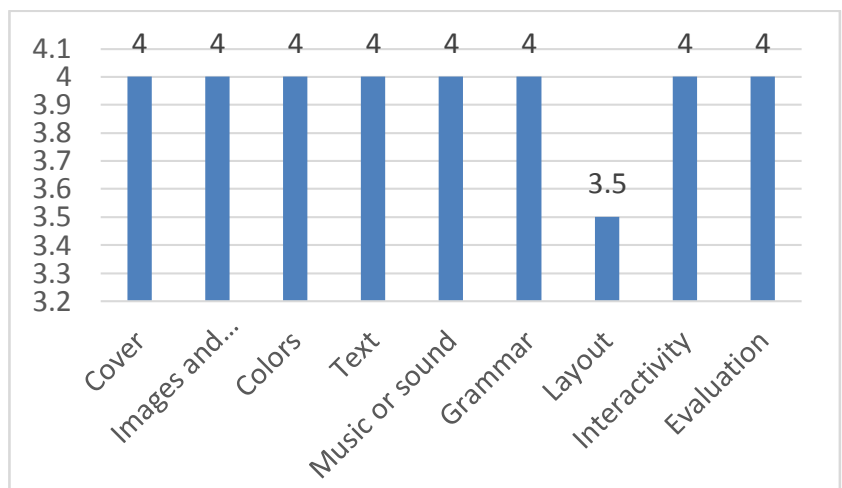

Fig. 3 The Media Expert's Assessment of The Lectora Inspire Learning Multimedia

d. Trial and revision phase

1. Initial trial.

The small group trial consisted of $6 \mathrm{X}$ grade students of Hospitality in Pontianak 5 State Vocational High School. Small group trial was chosen by random method, namely 2 students who have low abilities, 2 students who have moderate abilities, and 2 students who have high abilities. The process of this initial test, the researcher, prepares an observation sheet and participant questionnaire for students whose results of the questionnaire will be analyzed for input material for researchers in making improvements or revisions to learning multimedia so that the learning multimedia becomes better.

The average total response value of students is 2.80 or in the Good category. This means that the overall response of students to learning multimedia in the initial trial is good. The question or statement of the respondents in the initial trial consisted of 25 statements. The items in the questionnaire statement had a score of 1-4 so that the ideal score range of 25-100 was obtained. Some statements in the questionnaire need to be improved, namely statement number 3. The images presented are appropriate (not too much and not too little), number 4 (There is information on each picture presented in this multimedia), number 11 (Presentation of material in multimedia is related to other productive material or with other subjects in problemsolving and its application, number 18 (I can understand the terms used in this multimedia), and number 24 (With the illustrations in each beginning the material can provide motivation to study material welcoming guests).

The learning of the initial trial phase in this study still had several parts that had to be improved which included three aspects, namely the appearance, presentation of material and benefits. In the aspect of appearance, the part that must be repaired is the suitability of the number of images presented and the description of some of the images that are less clear. Improvements in the aspects of material presentation, namely the presentation of material in multimedia have not been fully related or integrated with productive material, or other subjects in problemsolving and its application and some terms used are unfamiliar or poorly understood. Furthermore, the beneficial aspects that must be corrected are illustrations at 
the beginning the material has not been fully able to provide motivation to study material welcoming guests, so the selection of more precise and interesting illustrations is highly recommended.

\section{Initial product revision}

After obtaining data about multimedia parts that must be corrected through comments and suggestions from students, then the researchers make improvements or revisions to the learning multimedia in accordance with the comments and suggestions of students to realize learning multimedia that is better than before. The improvement of learning multimedia that researchers have done from the results of the initial trial, namely: the number of images presented has been adjusted by considering several things including the clarity or effectiveness of the information conveyed to students and the duration of implementation during the learning process on the subject welcoming guests, each picture presented in multimedia have been briefly and clearly given information, the relationship between the material presented in learning multimedia with other productive material or other subjects in problem-solving and its application has been adapted to the expectations of the concepts of presented material in learning multimedia can also be integrated with other material and students will be helped in solving problems and their application, the terms used in learning multimedia have been adjusted, and illustrations at the beginning of each $\mathrm{m}$ the researcher has adjusted and is more interesting so that students are more motivated to learn material welcoming guests.

\section{Trial small group}

The second trial subject consisted of 9 students of XI grade Hospitality in Pontianak 5 State Vocational High School. The second trial was chosen by random method, namely 3 students who had low abilities, 3 students who had moderate abilities, and 3 students For those who have high abilities. The process of this second trial was researchers prepare observation sheets and questionnaires for students whose results of the questionnaire will be analyzed for input for researchers to make improvements or revise the learning multimedia so that the learning multimedia becomes better.

The initial trial phase in this study still had several parts that had to be improved which included three aspects, namely the appearance, presentation of material and benefits. In the aspect of appearance, the part that must be repaired is the suitability of the number of images presented and the description of some of the images that are less clear. Improvements in the aspects of material presentation, namely the presentation of material in multimedia have not been fully related or integrated with productive material, or other subjects in problem-solving and its application and some terms used are unfamiliar or poorly understood. Furthermore, the benefits aspects that must be corrected are illustrations at the beginning the material has not been fully able to provide motivation to study material welcoming guests, so the selection of more precise and interesting illustrations is highly recommended.

\section{Initial product revision}

After obtaining data about multimedia parts that must be corrected through comments and suggestions from students, then the researchers make improvements or revisions to the learning multimedia in accordance with the comments and suggestions of students to realize learning multimedia that is better than before. The improvement of learning multimedia that researchers have done from the results of the initial trial, namely: the number of images presented has been adjusted by considering several things including the clarity or effectiveness of the information conveyed to students and the duration of implementation during the learning process on the subject welcoming guests, each picture presented in multimedia have been briefly and clearly given information, the relationship between the material presented in learning multimedia with other productive material or other subjects in problem-solving and its application has been adapted to the expectations of the concepts of presented material in learning multimedia can also be integrated with other material and students will be helped in solving problems and their application, the terms used in learning multimedia have been adjusted, and illustrations at the beginning of each $\mathrm{m}$ the researcher has adjusted and is more interesting so that students are more motivated to learn material welcoming guests.

\section{Trial small group}

The second trial subject consisted of 9 students of XI grade Hospitality in Pontianak 5 State Vocational High School. The second trial was chosen by random method, namely 3 students who had low abilities, 3 students who had moderate abilities, and 3 students For those who have high abilities. The process of this second trial researchers was preparing the observation sheets and questionnaires for students whose results of the questionnaire will be analyzed for input for researchers to make improvements or revise the learning multimedia so that the learning multimedia becomes better.

The average total response value of students is 3.01 or in the Good category. This means that the overall response of students to learning multimedia in field trial is good.

\section{Product revision results of the second trial}

After obtaining data about multimedia parts that must be corrected through comments and suggestions from students, the researcher then repairs or revises the learning multimedia in accordance with the comments and suggestions of students to realize better and nearer learning multimedia. The improvement of learning multimedia that researchers have done from the results of the second trial, namely: the illustrations used have been adapted to the concepts to be explained through multimedia and more 
concrete, and the symbols or symbols used have been improved and adjusted so that it is easier to understand.

\section{Large Group Trial}

The large group testing phase was carried out for XI grade students of Hospitality in Pontianak 5 Vocational High School totaling 36 people with completed observation sheets and questionnaires for the contents of the students. The trial implementation of the field aims to find out the responses of students in taking lessons using learning multimedia and finding out the effectiveness of using learning multimedia on learning activities and skills of students in communicating English.

The field test was carried out based on the revised learning multimedia improvements according to suggestions and input from the previous stage, namely the field trial stage. Improvements in the results of the field trial phase are expected when conducting field tests better the learning process.

The average total response value of students is 3.36 or in the Very Good category. This means that the response of students to learning multimedia has increased towards a better direction.

Comparison of the average overall results of initial trial, small group trial, and large group trial is also presented in graphical form as shown in Fig. 4.

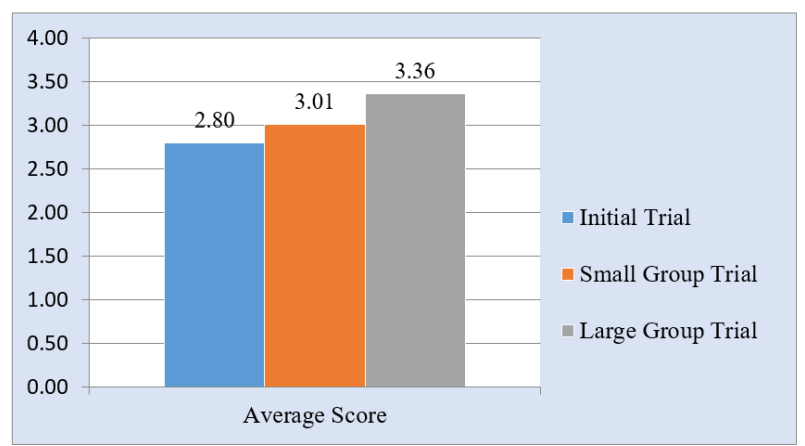

Fig. 4 Comparison of Learning Multimedia Test Results in Initial Trial, Small Group Trial, and Large Group Trial

Based on Figure 4, it shows that there has been an increase in values from the initial trial stage, small group trial to large group trial. Initial trial scores are seen at 2.80, lift them in good category. Comments and suggestions given by students at the initial trial stage are the basis for revising learning multimedia. The results of small group trial obtained a value of 3.01 or in the good category. Learning multimedia at this stage is also revised according to comments and suggestions from students. The results of a large group trial found a value of 3.36 with a very good category, which means that learning multimedia has approached the perfect stage and can be used in the learning process.

After the test phase of the field implementation is complete, then enter the sixth stage in ASSURE, namely evaluating and revising the learning program (evaluate and revise). Evaluating and revising learning multimedia is based on the results of comments and suggestions from students when conducting field tests to obtain better and perfect learning multimedia.

\section{B. Discussion}

Implementation of Learning Using Learning Multimedia to Improve English Communication Skills

The results of implementing learning using learning multimedia Lectora Inspire can be seen from the activities of students that take place during the learning process takes place. Observations are made by referring to the results of observations made by observers during the learning process.

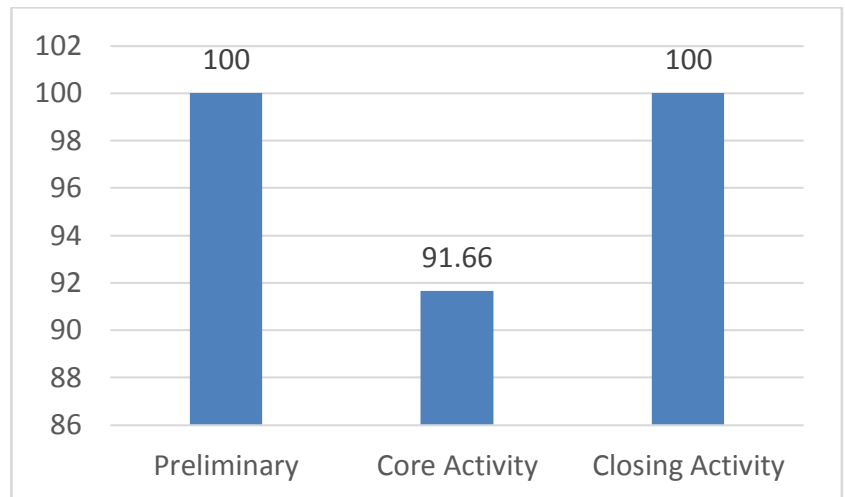

Fig. 5 Students Observation Graphics Using Multimedia Lectora Inspire

Conclusion on the implementation of interactive learning multimedia is able to make students active in using multimedia. The students seemed to have the courage to communicate and follow the vocabulary that appeared in English and seemed to be actively looking for the vocabulary they just knew. So that it can be interpreted that the communication skills in English appear to have increased, it can also be proven that many students work on evaluations and get a little error rate.

\section{Skills in communicating English after using multimedia Lectora Inspire.}

Use of Inspire multimedia Lectora on lessons Providing services Reception accommodation aims to facilitate students to be skilled in communicating in English. Communication skills can be seen when students have the courage to practice communicating English with confidence and get good evaluation scores or above KKM.

From the pretest implementation, the average score was 69.08. This value states that students have not achieved minimum completeness (KKM). Then the posttest shows an average value of 83.89 . This value states that students have achieved a score above the minimum completeness criteria (KKM) of 70 . Of the 36 students in total, 33 students have obtained scores above the KKM and as many as 3 students have not met the KKM. It can be concluded that the value of the acquisition of students tends to increase after using learning multimedia. This means that the use of Lectora Inspire's learning multimedia can contribute to improving the skills of students communicating in English. This can also be proven by the t-test conducted to determine the 
significant use of learning multimedia products. Based on the results of the statistical test, the t-test value is obtained by calculated $t=18,291$. The value of table with a level of confidence $=0.05, \mathrm{dk}=(\mathrm{n}-1)=36-1=35$ obtained a value of 2.030. Thus calculated $\mathrm{t}$ is greater than $\mathrm{t}$ table (tcount $=$ $18,291>\mathrm{t}$ table $=2,030)$. Based on the testing criteria that if tcount> ttable at $\alpha=0.05 \mathrm{dk}=35$, then it can be stated that there is the influence of using multimedia-based learning media on student learning outcomes . Thus, Ho is rejected, and $\mathrm{Ha}$ is accepted, which means that there are differences in student learning outcomes in communication skills.

During the learning process takes place can be seen the activity of students which is characterized by the involvement of students in communicating using English. For example, students follow vocabulary that can be heard with English pronunciation and mimic the dialogue contained in the relevant video. Students seem to actively seek the meaning of new words that have just been found by asking the teacher or researcher as well as searching for themselves in a large English dictionary. This shows that students have an interest in using the Lectora Inspire learning multimedia.

Thus overall through the use of Lectora Inspire learning multimedia can improve English communication of students and provide a good contribution in spurring the spirit of students to be skilled in communicating English.

\section{CONCLUSIONS}

Based on the results of research that has been done, it can be concluded that the use of Lectora Inspire's learning multimedia can improve students' English communication and make a good contribution in stimulating the spirit of students to be skilled in communicating English.

\section{REFERENCES}

Abdulhak, I. \& Darmawan, D. (2015). Teknologi Pendidikan. Bandung: PT Remaja Rosdakarya.

Cangara, H. (1998). Pengantar Ilmu Komunikasi. Jakarta: PT. RajaGrafindo Persada.

Cevich, J.M.I. (2006). Perilaku dan Manajement Organisasi. Jakarta: Erlangga.

Chatab, N. (2007). Profil Budaya Organisasi. Bandung: Alfabeta.

Gagne et al.(1992). Principle of Instrukctional Design. USA: Harcourt Brace Collage publishers.

Hermayawati. (2010). Penguasaan bahasa Inggris akan membuka wawasan terhadap perkembangan ilmu pengetahuan dan teknologi. Jurnal SosioHumaniora, 1(1).

Ngainun, N. (2017). Dasar-dasar Komunikasi Pendiidkan. Yogyakarta: Ar-Ruzz.

Purba, A. et al. (2006). Pengantar Ilmu Komunikasi. Medan: Pustaka Bangsa Press.

Sugiyono. (2016). Metode Penelitian Kuantitatif, Kualitatif, dan $R \& D$. Bandung: PT. Alfabeta.

Sukmadinata. (2006). Metode Penelitian Pendidikan. Bandung: PT. Remaja Rosdakarya.
Tedjasustina, A. (1994). Etika Komunikasi. Armico: Bandung.

Thornbury, S. (2016). Communicative language teaching in theory and practice. The Routledge handbook of English language teaching. Routledge. pp. 242-255. 